\title{
Pathology of knowledge strategy barriers in organization: a case study
}

\author{
Mehdi Kheirandish ${ }^{*}$
}

${ }^{a}$ Department of Management, Shahid Sattari Air University, Tehran, Iran

\begin{tabular}{l}
\hline A R T I C L E I N F O \\
\hline Article history: \\
Received April 28, 2012 \\
Received in Revised form \\
July, 29, 2012 \\
Accepted 10 August 2012 \\
Available online \\
14 August 2012 \\
\hline Keywords: \\
Knowledge management \\
Supreme audit company \\
Knowledge strategy
\end{tabular}

\begin{abstract}
A B S T R A C T
Knowledge management plays an important role on the success of organizations but there are several reasons that many organizations fail to talk a full advantage of the benefits of knowledge management implementation. In this paper, we perform an empirical investigation on supreme audit court organization of Iran. The survey uses a standard questionnaire and distributes 116 questionnaires among 228 people who worked for this organization. Cronbach alpha yields 0.817 , which is well above the minimum acceptable level. Kolmogorov-Smirnov test has been performed to examine the normality of the data and yields 1.71 for management attributes, 1.78 is for resource factors and 1.73 for environment factors and P-value for all three factors is 0.000 . The preliminary results of our survey indicate that management is the first important factor followed by resources and environment factors.
\end{abstract}

C 2012 Growing Science Ltd. All rights reserved.

\section{Introduction}

Recent changes in today's world have created tremendous challenges for organizations. Despite the difficulties these challenges have created, there will be some opportunities for business units. In such circumstances, only a limited numbers of organizations could succeed to use appropriate managerial tools to handle challenges and knowledge management (KM) is considered as one of the most important techniques (Ithia, 2003). Organizations are aware that knowledge plays an important role on creating competition and they do their best to learn more about KM and its capabilities. KM implementation could improve decision making processes, increase productivity, creativity and innovation, etc. Despite these advantages, KM implementation maintains some risks and one report approximates that nearly $84 \%$ of the KM implementations had no impact on organizations (Lucier, 1997). Nevertheless, understanding the reasons for not reaching success through KM implementation is also important since we can learn more about the reasons of failure and could possibly avoid them in future.

\footnotetext{
* Corresponding author. Tel: +989125021127

E-mail addresses: dr.me.kh@gmail.com (M. Kheirandish) 
The supreme audit court organization is one of the most important and the most powerful units where KM implementation plays an essential role for the success of such organizations. This organization does not have any competitor inside Iran but it faces with dynamic nature and competetive environment. In order to have better implementation of KM, organizations need to improve their positions through increasing effectiveness decisions. In this paper, we present an empirical study in Iranian suprime audit organization where the primary question is to learn whether there is a good infrastructure to execute KM in this organization or not. Chang et al. (2009) investigated the key factors for knowledge management in the national government of Taiwan. The achievements of the government KM initiatives reported two distinctive dimensions including core KM processes and KM performance including knowledge capture and transformation, business performance, and knowledge sharing and value addition.

There are increasing trend on using KM in organizations (Nordin et al., 2009) but many organizations do not use appropriate strategies to implement them (Rowlev, 1999). There are literally different definitions for KM but there is no precise and crystal clear definition for KM. Some people define $\mathrm{KM}$ is the challenge of detecting employees' personal capabilities and converting them into an appropriate intellectual asset, which could be used by others through a typical database. In other definition, $\mathrm{KM}$ is defined to decode raw data and interpret the extracted data into appropriate knowledge (Resnick, 2002). KM covers wide ranges of factors including design and implementation of culture and information technology (Wong, 2005). According to Chong (2006), the success of KM depends on carefully monitoring important factors influencing KM implementation. Chong et al. (2009) investigated whether the Malaysian telecommunication industry were ready for knowledge management implementation. We selected manufacturers as the respondents because they actively use and apply knowledge for the accomplishment of their tasks. Hung et al. (2005) performed another investigation on critical factors in adopting a knowledge management system for the pharmaceutical industry.

\section{The proposed model}

The proposed study of this paper attempts to detect three groups of issues influencing KM implementation, which are as follows,

1. Management attributes: This includes cooperation, control, leadership, etc. to prepare the necessary population.

2. Resource attributes: Knowledge, employee, financial and non-financial resources, etc.

3. Environment attributes: economic conditions, time and business characteristics.

In terms of objective, this study is a descriptive and in terms of application, this is an applied research, in terms of time horizon, this is a cross-sectional survey. The survey uses questionnaire and the sample size is calculated as follows,

$$
n=\frac{N \times z_{\alpha / 2}^{2} \times p \times q}{\varepsilon^{2} \times(N-1)+z_{\alpha / 2}^{2} \times p \times q},
$$

where $N$ is the population size, $p=1-q$ represents the yes/no categories, $z_{\alpha / 2}$ is CDF of normal distribution and finally $\varepsilon$ is the error term. Since we have $p=0.5, z_{\alpha / 2}=1.96$ and $N=228$, the number of sample size is calculated as $n=116$. Cronbach alpha yields 0.817 , which is well above the minimum acceptable level. Kolmogorov - Smirnov test has been performed to examine the normality 
of the data and yields 1.71 for management attributes, 1.78 is for resource factors and 1.73 for environment factors and P-value for all three factors is 0.000 . Therefore, we can conclude that all factors are normaly distributed.

\section{The results}

Since the distribution of all factors follow normal distribution, we could use t-student to examin all hypotheses, where the null hypothesis is $\mu \leq 3$ and alternative hypothesis is $\mu>3$. The null hypothesis for all hypotheses specify that the considered factors are not towards the supreme audit court's objectives. Table 1 shows details of our survey.

Table 1

The results of testing hypotheses

\begin{tabular}{lclllll}
\hline Factors & Frequency & Mean & t-student & df & P-value & Hypothesis \\
\hline Management & 116 & 4.44 & 24.51 & 115 & 0.00 & $\mathrm{H}_{0}$ is rejected \\
Resources & 116 & 4.29 & 21.63 & 115 & 0.00 & $\mathrm{H}_{0}$ is rejected \\
Environment & 116 & 4.18 & 15.69 & 115 & 0.00 & $\mathrm{H}_{0}$ is rejected \\
\hline
\end{tabular}

As we can observe from the results of Table 1, all null hypotheses are rejected when the level of significance is five percent and we can conclude that all factors are sufficiently helping supreme audit court's objectives. Therefore, this organization can establish knowledge management infrastructures within the organization. Next, we implement Freedman test to rank all factors, which yields 53.37 with two degrees of difficulty and P-value=0.000. Table 2 shows the results of our survey.

\section{Table 2}

The results of Freedman test

\begin{tabular}{llll}
\hline Number & Factor & Average ranking & Priority \\
\hline 1 & Management & 9.65 & First \\
2 & Resources & 8.69 & Second \\
3 & Environment & 8.61 & Thirds \\
\hline
\end{tabular}

\section{Conclusion}

Knowledge management plays an important role on the success of organizations and a successful implementation of knowledge management could increase productivity and profitability of business units. However, there are several requirements for the success of knowledge management implementation. We have presented an empirical investigation on supreme audit court organization and investigated the impacts of three management, resources and environment factors on the success of knowledge management. The results of our survey indicate that management is the first important factor followed by resources and environment factors.

\section{Acknowledgment}

The authors would like to thank the supreme audit court organization of Iran for their support on accomplishment of this project. We are also grateful for constructive comments on earlier version of this paper. 


\section{References}

Chang, M.Y., Hung, Y.C., Yen, D.C., \& Tseng, P. (2009). The research on the critical success factors of knowledge management and classification framework project in the Executive Yuan of Taiwan Government. Expert Systems with Applications, 36(3), 5376-5386.

Chong, S.C. (2006). Critical Success Factors to Knowledge Management Implementation: A Holistic Approach, Faculty of Business and Law Multimedia University, Jalan Ayer Keroh Lama, 75450 Melaka

Chong, C.W., Chong, S.C. \& Wong, K.Y. (2009). Is the Malaysian telecommunication industry ready for knowledge management implementation?. Journal of Knowledge Management, 13(1), 69-87.

Hung, Y.C., Huang, S.M., Lin, Q.P., \& Tsai, M.L. (2005). Critical factors in adopting a knowledge management system for the pharmaceutical industry. Industrial Management \& Data Systems, 105(2), 164-83.

Ithia, A. (2003). UK lawyers spend more on KM. KM Review, 79(3), 106-116.

Lin, Y.C., \& Lin L.K. (2006). Critical success factors for knowledge management studies in construction. Department of Civil Engineering National Taipei University of Technology

Lucier, C., \& Torsiliera, J. (1997), Why knowledge programs fail, strategy and business, 4th quarter.

Nordin, M, Pauleen, D., \& Gorman, G.E. (2009). Investigating KM antecedents: KM in the criminal justice system. Journal of Knowledge Management, 13(2), 4-20.

Resnick, M. (2002). Knowledge management, Available at Google sight.

Wong, K.Y. (2005). Critical success factors for implementing knowledge management in small and medium enterprises. Industrial Management \& Data Systems, 105(3), 261-79. 